\title{
126. Further Purification and Component Analysis of Commelinin Showing the Presence of Magnesium in this Blue Complex Molecule*)
}

\author{
Studies on Anthocyanins, LXII**)
}

\author{
By Kôzô HAYashi and Kôsaku TAKEDA***) \\ Botanical Department, Faculty of Science, Tokyo Kyoiku University \\ (Comm. by Yuji Shibata, M. J.A., June 12, 1970)
}

According to the literature, a unique group of metallo-anthocyanins includes two kinds of crystalline, blue metal complexes, i.e., commelinin first isolated by one of us (K.H.) ${ }^{1)}$ from the dayflower, and protocyanin obtained by E. Bayer2) from the cornflower. These pigments have different metallic components. The essential metal is $\mathrm{Mg}$ in commelinin, whereas both $\mathrm{Fe}$ and $\mathrm{Al}$ are found in protocyanin. However, incompatible opinions have been expressed concerning the nature of metallic components in both complexes. Based on their analysis of well-defined crystals, K. Hayashi and co-workers ${ }^{3)}$ have stated that the metals in protocyanin are $\mathrm{Fe}, \mathrm{Mg}$ and $\mathrm{K}$, and that $\mathrm{Al}$ is not present in the purified pigment contrary to the report of $\mathrm{E}$. Bayer. In recent years, exhaustive purification of this pigment has been reported by S. Asen and L. Jurd.4) They isolated a blue crystalline pigment (cyanocentaurin) having the structure which is essentially analogous to commelinin rather than protocyanin. Moreover, they stated that X-ray fluorescence measurements established the presence of $\mathrm{Fe}$ and a complete absence of other metals in their preparation.

In the mean time, the structure of a pale yellow flavonoid pertaining to the complex molecule of commelinin was determined by us to be a $4^{\prime}$-glucoside of swertisin (called flavocommelin) ${ }^{5)}$ belonging to the class of $C$-glycosylflavones.

On the other hand, E. Bayer has persisted in the view that the presence of $\mathrm{Mg}$ in commelinin must be due to impurities, since a divalent metal such as $\mathrm{Mg}$ in general cannot be regarded as a central metal capable of forming any stable complex compounds. Indeed, this may be convincing from a ordinary chemical conception of

*) Orally presented at the XI International Botanical Congress held at Seattle in Aug. to Sept. (1969).

**) Part LXI of this series: Bot. Mag. Tokyo, 82, 155 (1969).

***) Present address (K.T.): Dept. of Botany, Faculty of Science, University of Tokyo. 
valency, but for the moment it is necessary to begin with the basic question of whether or not magnesium is really present in commelinin. In order to answer this question, the present experiments were done using a freshly prepared, crystalline specimen of commelinin, which, then, was further purified by Sephadex column chromatography. The results indicate that $\mathrm{Mg}$ is an essential component of this blue pigment complex, and it was not lost even following a repetition of the purification procedure.

The quantitative analyses of this preparation have led us to propose an important change in the molecular ratio of the four components in commelinin; that is, awobanin 2 mols, flavocommelin 2 mols, and magnesium 1 atom. In addition, an indefinite number of potassium atom is involved, probably as phenolic salts. For the sake of convenience, the structure of this complex molecule may be expressed by the model shown below:

\section{Provisional structure of commelinin molecule}

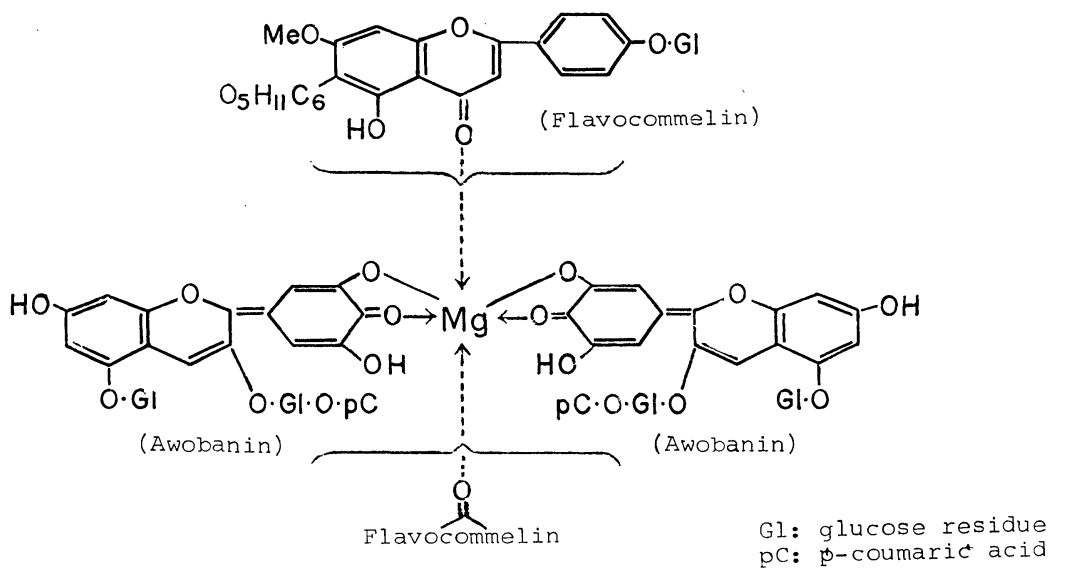

Of course, this model was proposed so as to satisfy the co-ordination number ' 6 ' usually assigned to magnesium. Further detail on molecular conformation is beyond the scope of the present experiments. This is an important task to be solved in the future by physico-chemical investigations.

Experimental. Isolation and purification of commelinin. This process was principally the same as reported previously up to the step of crystallization. A new final purification step, Sephadex column chromatography, was applied in this experiment. The whole process is shown diagrammatically below: 


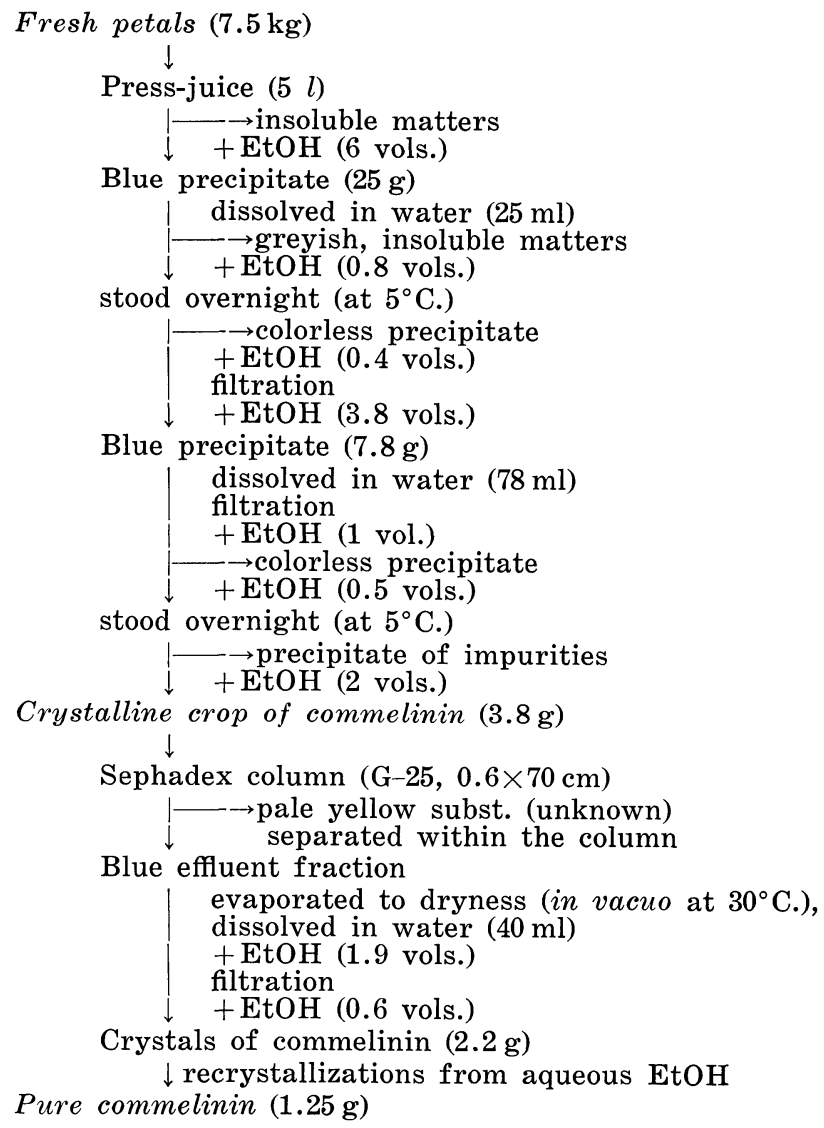

The final crop of commelinin was obtained in the form of brilliant, deep blue, rectangular prisms (Fig. 1). It gave a single spot on the paper chromatogram as well as on the paper electropherogram, as reported previously. Among the mineral components remaining after combustion of this commelinin, magnesium was clearly detected

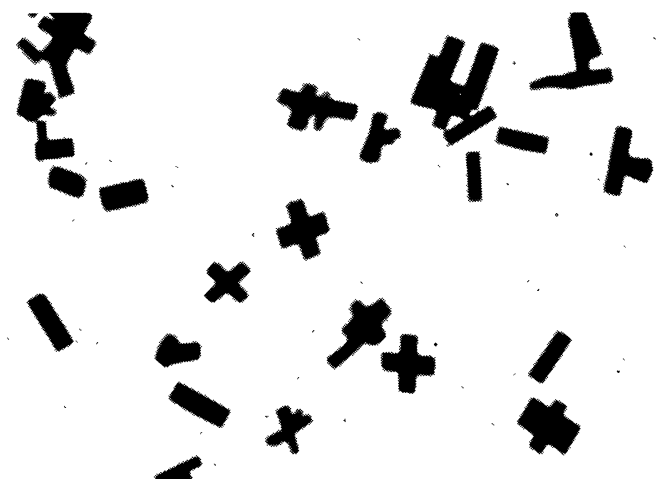

Fig. 1. Commelinin ( $\times$ ca. 250). 
by color reactions on the filter paper; namely, blue with magneson reagent and violet with alizarine in the presence of ammonia vapor. All other properties were same as those described earlier. ${ }^{1)}$

Quantitative measurement of individual components in commelinin. In order to minimize the loss of the components caused by drastic treatment, commelinin was degraded by $2 \%$ hydrochloric acid at room temperature, and resultant products were determined by spectrophotometric analysis.

Awobanin chloride (delphinidin 3-p-coumaroylglucosido-5-monoglucoside). Anhydrous commelinin was dissolved in a definite amount of $60 \% \mathrm{EtOH}$ containing $2 \% \mathrm{HCl}$, and the awobanin chloride liberated was determined by its absorbance at $540 \mathrm{~m} \mu$. The calibration curves of molar absorbance was prepared with authentic specimens of violanin and tulipanin chlorides, which have been shown to be applicable to molar determinations of awobanin with or without flavocommelin (co-pigment). The results are shown in Table I.

Table I. Colorimetric determination of awobanian liberated from commelinin

\begin{tabular}{l|cc}
\hline $\begin{array}{c}\text { Commelinin } \\
\text { (anhydrous) }\end{array}$ & $\begin{array}{c}\text { Awobanin chloride } \\
\text { (determined by the absorbance at } 540 \mathrm{~m} \mu \text { ) }\end{array}$ \\
\hline $4.709 \mathrm{mg}$ & $2.388 \mathrm{mg}$ & $50.71 \%$ \\
4.183 & 2.190 & 52.35 \\
\hline & Mean & 51.53 \\
\hline
\end{tabular}

Flavocommelin (6-C-glucosylgenkwanin 4'-O-glucoside). A definite amount of the above acidic solution of commelinin was streaked on Tôyô No. 51 filter paper $(13 \times 40 \mathrm{~cm})$, and developed with the Forestal solvent $\left(\mathrm{AcOH} / \mathrm{HCl} / \mathrm{H}_{2} \mathrm{O}=30: 3: 10\right.$, v/v). After drying the chromatogram in the air, the pale yellow band of flavocommelin was eluted thoroughly with $0.05 \mathrm{M}$ acetate buffer ( $\mathrm{pH} 4.8$ ), and the amount of flavocommelin was calculated from its absorbance at $329 \mathrm{~m} \mu$. The calibration ocurve was prepared with flavocommelin crystals dissolved in the same buffer by measuring the absorbance at $329 \mathrm{~m} \mu$. Here it must be mentioned that the elution from the paper with the above buffer solution is practically complete. The results of seven experiments are shown in Table II.

Content of $M g$. Weighed amounts of anhydrous commelinin were dissolved in definite amounts of water in seven flasks, and magnesium was estimated in ppm by the method of atomic absorption. The measurements were made by Mr. T. Takata in the laboratory of Prof. Kunio Nakano, Chemistry Department, Rikkyo University in Tokyo. The mean of the values obtained by seven experi- 
Table II. Analytical values of flavocommelin and $\mathrm{Mg}$ in commelinin

\begin{tabular}{c|c|c|c}
\hline & $\begin{array}{c}\text { Samples applied } \\
(\mathrm{mg})\end{array}$ & $\begin{array}{c}\text { Flavocommelin } \\
\text { (MW. 604) }\end{array}$ & $\begin{array}{c}\text { Magnesium } \\
\text { (AW. 24.3) }\end{array}$ \\
\hline \multirow{2}{*}{ Specimen 1 } & 6.547 & $39.45 \%$ & $0.687 \%$ \\
& 5.483 & 41.33 & 0.706 \\
& 7.477 & 39.90 & 0.752 \\
Specimen 2 & 5.034 & 39.23 & 0.695 \\
& 4.057 & 40.05 & 0.690 \\
& 5.952 & 38.78 & 0.672 \\
& 7.025 & 40.09 & 0.693 \\
\hline
\end{tabular}

Table III. Analysis of individual components in commelinin

\begin{tabular}{|c|c|c|c|c|}
\hline $\begin{array}{l}\text { Components } \\
\text { of } \\
\text { commelinin }\end{array}$ & $\begin{array}{l}\text { Molecular } \\
\text { or } \\
\text { atomic weight }\end{array}$ & $\begin{array}{l}\text { Number of } \\
\text { molecules } \\
\text { or atoms }\end{array}$ & $\begin{array}{c}\text { Theoretical } \\
\text { values }\end{array}$ & $\begin{array}{c}\text { Experimental } \\
\text { values } \\
\text { (average) }\end{array}$ \\
\hline Awobanin & 773 & 2 & $55.64 \%$ & $51.53 \%$ \\
\hline Flavocommelin & 604 & 2 & 43.47 & 39.83 \\
\hline $\mathrm{Mg}$ & 24.3 & 1 & 0.87 & 0.70 \\
\hline $\mathrm{K}$ & 39.1 & 1 & 1.38 & 0.86 \\
\hline \multicolumn{2}{|c|}{ Total } & $\begin{array}{l}2817.4 \text { ) } \\
0 \% \text { (after D }\end{array}$ & $\begin{array}{r}99.98 \\
\text { s-Pregl) }\end{array}$ & 92.92 \\
\hline
\end{tabular}

ments for $\mathrm{Mg}$ was $0.700 \%$ of the weight of anhydrous commelinin, as shown in Table II.

Content of $K$. As has been indicated by previous experiments, potassium is present as a phenolic salt in commelinin, and it is apt to be lost during the process of purification. Therefore, the content of potassium seems to be less stable than the other three components of commelinin. In fact, a flame spectrophotometric determination of this metal in the purest specimen obtained above gave a value of $0.86 \%$; this is about one half of the theoretical value corresponding to one potassium atom.

The test for $\mathrm{N}$ content in commelinin using the method of DumasPregl was negative.

Summary of the analytical results. In order to furnish a sound basis for further research on the structure of the blue complex molecule in question, the results of quantitative analyses on the purest specimen obtained here may be summarized in Table III. As mentioned above, the value of two components of this pigment, awobanin and flavocommelin, are almost same as those of the previous experiments, whereas the value for $\mathrm{Mg}$ is nearly twice as high as that obtained before. This fact accounts for the alteration of the mole- 
cular ratio to $2: 2: 1$ from $4: 4: 1$ for awobanin, flavocommelin and $\mathrm{Mg}$, respectively.

Acknowledgement. The authors wish to express their sincere thanks to Emeritus Professor Yuji Shibata, a forerunner of the anthocyanin-metal complex theory, for his deep interest and helpful suggestions during this investigation. Thanks are also due to the analytical chemists, Prof. K. Nakano (Rikkyo University in Tokyo) and Prof. K. Nagashima (Tokyo Kyoiku University) for the atomic absorption analysis of magnesium. The authors' appreciation is to be given to Dr. J. E. Sherwin for his kind revision of the manuscript.

This work was supported in part by the grant for the promotion of science awarded by the Ministry of Education.

\section{References}

1) K. Hayashi: Pharmazie (Berlin), 12, 245 (1957); K. Hayashi, Y. Abe, and S. Mitsui: Proc. Japan Acad., 34, 373 (1958); S. Mitsui, K. Hayashi, and Sh. Hattori: ibid., 35, 169 (1959); Bot. Mag. Tokyo, 72, 326 (1959).

2) E. Bayer: Chem. Ber., 91, 1115 (1958).

3) K. Hayashi, N. Saitô, and S. Mitsui: Proc. Japan Acad., 37, 393, 485 (1961).

4) S. Asen and L. Jurd: Phytochem., 6, 577 (1967).

5) K. Takeda, S. Mitsui, and K. Hayashi: Bot. Mag. Tokyo, 79, 578 (1966); M. Komatsu, T. Tomimori, K. Takeda and K. Hayashi: Chem. Pharm. Bull., 16, 1413 (1968).

6) E. Bayer: Chimia, 16, 333-337 (1962); E. Bayer, H. Egeter, A. Fink, K. Nether und K. Wegmann: Angew. Chem., 78, 834-841 (1966). 